сьогодення [Електронний ресурс]/ Алла Колупаєва. - Режим доступу : http://slovyanochka.at.ua 6. Правительственный портал [Електронний ресурс].- Режим доступу : http://www.kmu.gov.ua

\title{
СТАНОВЛЕННЯ ТВОРЧОЇ ОСОБИСТОСТІ ЧЕРЕЗ СИСТЕМУ ФІЗИЧНОЇ КУЛЬТУРИ ТА ЗДОРОВИЙ СПОСІБ ЖИТТЯ МАЙБУТНІХ УЧИТЕЛІВ
}

Андріанов В. С., Андріанов Т. В. Становлення творчої особистості через систему фізичного виховання та здоровий спосіб життя майбутніх учителів.

У статті розкриваються особливості формування звички до здорового способу життя як невід'ємного компонента становлення творчої особистості майбутнього вчителя в системі фізичного виховання. Акцентується увага на важливості застосування активних форм навчання на заняттях з фізичного виховання.

Ключові слова: здоровий спосіб життя, рух, творча особистість, фізичне виховання, студент.

Андрианов В. Е., Андрианов Т. В. Становление творческой личности через систему физического воспитания и здоровый образ жизни будущих учителей.

В статье раскрываются особенности формирования привычки к здоровому образу жизни как неотъемлемого компонента становления творческой личности будущего учителя в системе физического воспитания. Акцентируется внимание на важности применения активных форм обучения на занятиях по физическому воспитанию.

Ключевые слова: здоровый образ жизни, движение, творческая личность, физическое воспитание, студент.

Andrianov V. Ye., Andrianov T. V. The formation of a creative personality through the system of physical education and healthy lifestyle of the future teachers.

The article defines peculiarities of the formation of habits for a healthy lifestyle as an integral component of formation of a creative personality of the future teacher in the system of physical education. The attention is focused on the importance of application of active forms of education in physical training classes.

Key words: healthy lifestyle, motion, creative personality, physical education, a student.

Сучасна система фізичної культури максимально наближається до життєвих потреб людини, яка повинна усвідомлювати, що заняття фізичними вправами, спортом зберігають і зміцнюють її здоров'я, здійснюють освітній, оздоровчий і виховний вплив, формують творчу особистість, упевнену у своїх силах.

Творча особистість у системі фізичного виховання- це пізнання самого себе, сформовані цінності, потреби, звички, інтерес до фізичної культури, мотиви бути здоровим, життєрадісним, працездатним. Система фізичного виховання детально дозволяє пізнати психофізичну сферу особистості - моторну, вольову, емоційну, сенсорну, когнітивну, що цілком відповідає основній меті всебічного та гармонійного розвитку сучасної особистості.

Визначаючи структуру творчої компетенції особистості, фахівці з фізичної культури 
розкривають загальні закономірності культури особистості. Це означає, що студент оволодіває знаннями, практичними вміннями й навичками, творчими здібностями, набуває почуття радості і задоволення.

Водночас слід наголосити на тому, що в сучасній системі фізичного виховання проблема формування творчої особистості реалізується недостатньо. Ми у своїй роботі спираємося на такі методичні праці оздоровчо-культурологічного й освітньо-виховного спрямування таких дослідників: К. Габрієлян, С. Гвоздій, Ю. Григор'єва, І. Іванова, А. Козикіна, Т. Маляренко, Р. Узянбаєва, Л. Пахомова, Л. Поліщука, А. Щедрина, І. Беха, Г. Ващенка, Т. Глазько, Д. Давиденка, Р. Купчинова, С. Лапаєнко, С. Омельченка, Н. Паніної, Т. Титаренко, Ю. Щедрина, О. Яременка та інших.

Отже, можна стверджувати, що потребують утілення конкретні ідеї, теоретичні розробки та методики, спрямовані на формування життєво важливих рухових навичок i розвиток фізичних якостей, звички до здорового способу життя як невід’ємного компонента творчої особистості в системі фізичного виховання. Тому нині фахівці з фізичної культури та спорту у своїй роботі здійснюють складний пошук нових методик та методів, що будуть сприяти формуванню звички дотримуватися здорового способу життя, правил гігієни, уникати шкідливих звичок, що є актуальною проблемою сьогодення.

Mema cmammi: теоретично та методично обгрунтувати формування звички до здорового способу життя як невід'ємного компонента становлення творчої особистості майбутнього вчителя в системі фізичного виховання.

Одним із найважливіших завдань вищої школи в розділі «Фізичне виховання» $\epsilon$ розвиток творчої особистості, що дає змогу студентам у процесі навчання оволодіти теоретичними знаннями з основ здоров'я, а також набути практичних навичок здорового способу життя.

Проблемі формування здорового способу життя присвячено дослідження таких вітчизняних науковців, як: В. Агарова, Н. Бугашева, Г. Голобородька, Н. Завидівської, С. Лапаєнка, В. Ніколаєнка та багатьох інших. 3 позиції сучасних дослідників, фізичне виховання повинно стати одним із пріоритетних напрямків освіти, визначальним чинником у процесі формування навичок здорового способу життя як практичної дисципліни, що сприяє усвідомленню студентами сутності здорового способу життя та вчить практичним діям задля зміцнення і збереження здоров'я [6, с. 176].

Поняття «здоровий спосіб життя» включає фізичне, духовне та соціальне здоров'я. Взаємозумовленість цих понять виступає не сукупністю, а результатом їх розвитку. Якщо будь-який 3 трьох цих компонентів дорівнюватиме нулю, то й загальний показник дорівнюватиме нулю [1, с. 11].

Інтеграція до європейського освітнього простору спонукає викладачів фізичного виховання впроваджувати у навчальний процес прогресивні науково-педагогічні технології, які відповідають потребам творчої особистості. Саме на основі виховання у студентів творчої компетентності щодо фізичного вдосконалення (збагачення творчого потенціалу) починають розвиватися такі професійно важливі якості, як рівень знань і відповідні педагогічні уміння творчого характеру задля підвищення розумової працездатності та покращення здоров’я. У сучасній науковій літературі виокремлено певні принципи компетентнісного підходу щодо формування творчої особистості, підкреслюється, що ставлення до свого здоров’я як цінності і розвиток здоров'язбережувальних компетентностей педагога забезпечує високий рівень здоров'я, озброює необхідним багажем знань, умінь і навичок, необхідних для реалізації здорового способу життя та виховання в учнів високої культури здоров'я [3, с. 35]. 
Слід зазначити, що аналіз літературних джерел і вивчення практичного досвіду показали, що близько $75 \%$ дорослого населення, у тому числі $62 \%$ осіб студентського віку, мають низький і середній рівень фізичного здоров'я, неефективно використовують основи і принципи здорового способу поведінки в повсякденному житті.

Студентські роки характеризуються певними тенденціями щодо умов, форм і побуту та взаємозв'язками між особистим і громадським життям, саме через здоровий спосіб життя формується життєвий досвід удосконалення знань, що відповідають потребам сьогодення. Суспільство створює умови для творчих виявів особистості, яка володіє певним переліком якостей, а саме: рішучістю, умінням не зупинятися на досягнутому, сміливістю мислення, наполегливістю.

Упевненість у своїх фізичних і психічних можливостях - найважливіша умова розкриття потенційних можливостей особистості студента. Упевненість у собі- важливе джерело мотивації у повсякденному житті. Цілеспрямованому культивуванню впевненості у студентські роки може сприяти активна спортивна діяльність. Результати дослідження показали, що спортивна діяльність сприяє розвитку впевненості, оскільки у студентів, які займаються спортивною діяльністю, зафіксовано нижчий рівень невпевненості порівняно зі студентами, які спортивною діяльністю не займаються [2, с. 675].

Творча особистість майбутнього вчителя виникає лише внаслідок наявності у неї творчих здібностей, мотивів, знань i вмінь, завдяки яким створюється новизна, оригінальність, унікальність іiі майбутньої педагогічної діяльності. За визначенням С. Сисоєвої, професійно-педагогічна діяльність - творча діяльність, якій притаманні властивості творчого та дослідницького процесу [4, с. 97].

Творчий підхід майбутнього педагога при доборі ігор і вправ на заняттях фізичною культурою сприяє формуванню звички до здорового способу життя, дозволяє здійснювати самоконтроль за власним здоров'ям.

Формування творчої спрямованості особистості до фізичної культури - це оволодіння теоретичними основами, створення бази педагогічних навичок та вмінь під час виконання фізичних вправ і засвоєння знань з фізичного виховання.

Фізичні вправи впливають на розвиток і зміцнення м'язових груп плечового поясу, шиї, тулуба, ніг, сприяють формуванню правильної постави, підвищують рухливість суглобів і працездатність аеробної функції, покращують роботу всіх органів і систем організму. При цьому необхідно прагнути до самовдосконалення творчих здібностей на основі проектування фізичного навантаження.

Фізична підготовка - головна ознака творчої особистості. Майбутній педагог повинен уміти керувати своїм руховим режимом у добовому та тижневому біологічному ритмі, який передбачає правильну організацію сну, харчування та різні види рухової активності.

При проведенні оздоровчих заходів необхідно підтримувати постановку пізнавальних проблем, розв'язанням яких є творча активність і творче переосмислення кожної фізичної вправи, віра у свої сили, можливості і здібності та впевненість у творчому успіху. Варто враховувати ступінь складності фізичних вправ і творчу активність під час виконання, забезпечувати атмосферу психологічного та фізичного комфорту.

Фізична культура та спорт є творчим процесом, і тому на заняттях можна формувати мотивацію творчої діяльності під час використання активних форм навчання.

Важливим у реалізації завдань системи фізичного виховання студентів є знання їх особистісних якостей, фізичного та психічного здоров'я, стійкість нервової системи до різних видів подразнень, інтересів, можливостей. Здоровий спосіб життя та фізичний розвиток 
студента забезпечує лише оптимальний руховий режим, зумовлений закономірностями, психологічними й анатомо-фізіологічними потребами. У процесі виховання здорового способу життя в особистості розвивається стійке й усвідомлене ставлення до здоров'я, зумовлене позитивними інтересами та потребами, прагнення до вдосконалення власного здоров'я, творчості й духовного світу [5, с. 163].

Нами було проведено дослідження педагогічних умов формування звички до здорового способу життя через використання системи фізичного виховання студентів педагогічного інституту. У студентські роки вибір способу життя є відповідальним рішенням у житті творчої особистості. Формуючи у студентів звичку здорового способу життя, ми використовували засоби, що дозволяли студенту вірити у свої сили і можливості, знаходити певний шлях до себе та давали можливість успішно корегувати якості повноправної фізично розвиненої особистості суспільства.

Нами було розроблено комплексну програму педагогічних впливів на студентів щодо формування здорового способу життя. Характерною рисою комплексної програми педагогічного впливу на формування здорового способу життя є вплив на мотиваційноціннісну, емоційно-вольову та природну потребу, формування іï у стійку норму поведінки. Наші дослідження дозволили виявити ті умови формування потреби здорового способу життя, які вимагають здійснення сучасних психолого-педагогічних та фізкультурнооздоровчих впливів на студентське життя. Так, аналізуючи одержані дані, можна стверджувати, що процес формування здорового способу життя в дослідноекспериментальній групі мав творчу професійно-педагогічну спрямованість, а рівень фізичної активності дозволяє наголосити на компетентності студента щодо власного здоров'я (показники сформованості здорового способу життя наприкінці експерименту зросли). Це свідчить, що компетентність майбутніх фахівців освітянської галузі щодо формування здорового способу життя є важливою і зумовлюється об' єктивними суспільними потребами професійної підготовки майбутніх учителів 3 урахуванням їх інтересів та побажань.

За результатами нашого дослідження, фізична активність, як умова мотивації щодо здорового способу життя і експрес-інформація про свій фізичний стан, наявна у 67,3\% студентів, а 40,6 \% студентів не могли дати чіткої відповіді про своє ставлення до культури здорового способу життя, оскільки мають шкідливі звички (тютюнопаління та вживання алкоголю).

Ефективність комплексної програми в дослідно-експериментальній роботі вказує на те, що перш ніж формувати звичку до здорового способу життя, необхідно розширити теоретичні знання та практичні вміння 3 сучасної оздоровчої системи, застосовувати спеціальні комплекси фізичних вправ чи засобів, які впливають на розвиток творчих здібностей, підвищують творчу активність майбутніх педагогів, що є необхідною умовою для готовності їх до раціональної організації праці та відпочинку, гігієни тощо. Відтак фізкультурно-оздоровча діяльність повинна бути спрямована на формування творчої особистості у всій повноті іï сутнісних сил, що є культурою здорового способу життя.

За період дослідної роботи завдяки набутим знанням, творчому підходу до керування своїм руховим режимом у добовому, тижневому та річному циклі позитивне ставлення до здорового способу життя в майбутніх учителів досягло 95,3\%. Це вказує на необхідність внесення коректив як до змісту навчання, так і до процесу трансляції знань, формування вмінь і навичок.

У процесі розроблення експериментальної програми в основу формування звички до 
здорового способу життя були покладені такі напрямки:

- оздоровчо-профілактичні заходи, включаючи лікарський контроль; аналіз причин захворювання; індивідуальний підхід у разі необхідності реабілітації на основі біомедичних даних і результатів тестування; використання спеціальних відновлювальних заходів під час і після виконання фізичних вправ;

- зміна структури рухової активності; модернізація змісту анатомо-фізіологічного складника біологічно-валеологічної освіти; перерозподіл навчального часу на основі застосування інноваційних та тренінгових методик;

- встановлення міжпредметних зв'язків з анатомією і фізіологією людини, основами гігієни; формування інструктивних навичок і вмінь самостійно займатися фізичними вправами, здійснювати самоконтроль за власним станом здоров'я;

- комплексний підхід щодо виховання високої культури особистої гігієни, санітарії, загартовування.

Уважаємо, що під час визначення етапів формування звички здорового способу життя у майбутніх фахівців освітянської галузі необхідно враховувати соціальну ситуацію, що характеризує кожний етап студентського віку, умови й чинники педагогічного процесу та показники здоров'я.

Можна стверджувати, що окреслена проблема спрямована на фізкультурно-оздоровчу діяльність, яка відкриває для студентів щось нове, стимулює їх інтерес, потребу, звичку, зумовлює формування творчої компетентності 3 невід'ємними складниками здорового способу життя.

Модернізація дисципліни «Фізичне виховання»у ВНЗ - це сукупність ефективних методів, форм і засобів, що дозволяє збільшити рухову активність на заняттях з фізичного виховання, формує творчий стиль діяльності і самостійність творчо мислити, спрямованих на зміцнення здоров'я, підвищення функціональних можливостей організму до здорового способу життя. Формування звички до здорового способу життя сприяє підвищенню рівня загальної і спеціальної підготовки й дієздатності функціональних систем організму, розвитку сили різних груп м'язів, розвитку рухових здібностей, спрямованих на творчість щодо оздоровчої та спортивної діяльності. Доцільне використання творчих дій у системі фізичного виховання, безперечно, залежить від особистості, iї творчості та майстерності.

Отже, формування творчої особистості, яка володіє знаннями, вміннями та навичками фізичної культури, є об’єктивною передумовою іiі професійної компетентності, є тією основою, на якій формується інтелектуальний, духовний і фізичний потенціал.

\section{Література}

1. Баканова А. Ф. Формирование здорового образа жизни студенческой молодежи / А. Ф. Баканова // Физическое воспитание студентов. - 2011. - № 6. - С. 8-11. 2. Марчик В. І. Вплив спортивної діяльності на розвиток впевненості в залежності від успішності навчання / В. І. Марчик, І. Л. Мінжоріна // Фізична культура, спорт та здоров'я нації : [зб. наук. праць] / гол. ред. В. М. Костюкевич. - Вінниця : ТОВ «Планер», 2015. - Вип. 19. - Т. 2. - С. 672-679. 3. Радіонова О. Місце компетентності здоров'язбереження в структурі компетентності педагога/ Олена Радіонова // Валеологічна освіта в навчальних закладах України: стан, напрямки й перспективи розвитку: XXI Всеукр. наук.-практ. конф. (Кіровоград, 21-23 травня 2015 року) : [матеріали конференції]. - Кіровоград : КДПУ ім В. Винниченка, 2015. - С. 132137. 4. Сисосва С. О. Основи педагогічної творчості: [підручник] / С. О. Сисоєва. - Київ : Міленіум, 2006. - 344 с. 5. Стасюк В. Виховання спрямованості на формування здорового способу жяття: проблема визначення / Василь Стасюк, Леонід Олейник // Валеологічна 
освіта в навчальних закладах України: стан, напрямки й перспективи розвитку: XXI Всеукр. наук.-практ. конф. (Кіровоград, 21-23 травня 2015 року) : [матеріали конференції].Кіровоград : КДПУ ім В. Винниченка, 2015. - С. 158-163. 6. Титаренко А. А. Формирование здорового образа жизни у студенческой молодежи / А. А. Титаренко // Актуальні проблеми медико-біологічного забезпечення фізичної культури, спорту та реабілітації : I Міжн. наук.практ інтер.-конф. (Харків, 23 квітня 2015 року): [збірник доповідей]. - Харків : ХДАФК, 2015. - C. 173-176.

УДК $37.013 .42(075.8)$

Екатерина Беляева

\section{ИССЛЕДОВАНИЕ ГОТОВНОСТИ БУДУЩИХ СОЦИАЛЬНЫХ ПЕДАГОГОВ К СОЦИАЛЬНО-ПЕДАГОГИЧЕСКОМУ СОПРОВОЖДЕНИЮ ОДАРЕННЫХ ШКОЛЬНИКОВ}

Беляєва К. Ю. Дослідження готовності майбутніх соціальних педагогів до соціальнопедагогічного супроводу обдарованих школярів.

У статті розглянуто основні положення про використання діагностичного інструментарію для дослідження готовності майбутніх соціальних педагогів до соціальнопедагогічного супроводу здібних учнів та засобів її формування, вказано основні методики й результати дослідження, проведеного зі студентами ВНЗ.

Ключові слова: соціальний педагог, соціально-педагогічний супровід, діагностика, готовність.

Беляева К. Ю. Исследование готовности будущих социальных педагогов к социальнопедагогическому сопровождению одаренных школьников.

В статье рассмотрены основные положения о использовании диагностического инструментария для исследования готовности будущих социальных педагогов к сопровождению одаренных учеников и средства ее формирования, указаны основные методики и результаты исследования, проведенного со студентами вузов.

Ключевые слова: социальный педагог, социально-педагогическое сопровождение, диагностика, готовность.

Belyaeva K. Yu. The study of future social teachers' readiness for social and educational support of gifted pupils.

The article deals with the basic statements about the use of diagnostic tools to identify the readiness of the future social teachers to support gifted pupils and means of its formation. The basic techniques and results of the study carried out with university students are given.

Key words: social teacher, social and educational support, diagnostics, readiness.

На современном этапе развития общества приоритетным заданием в системе высшего образования остается качественная подготовка будущих социальных педагогов, умеющих эффективно организовывать свою деятельность, осуществлять сопровождение одаренных школьников, их окружения, создавать условия для раскрытия талантов и способностей ребенка, поддержки его на государственном уровне. При этом важно учесть, что рост потребности общества в квалифицированных специалистах, способных влиять на решение социальных проблем, вызывает необходимость их профессиональной подготовки. 